\title{
THE EVOLUTION OF THE DESIGN AND CONSTRUCTION OF MASONRY BUILDINGS IN AUSTRALIA
}

\section{Adrian Page email $^{\text {ema }}$}

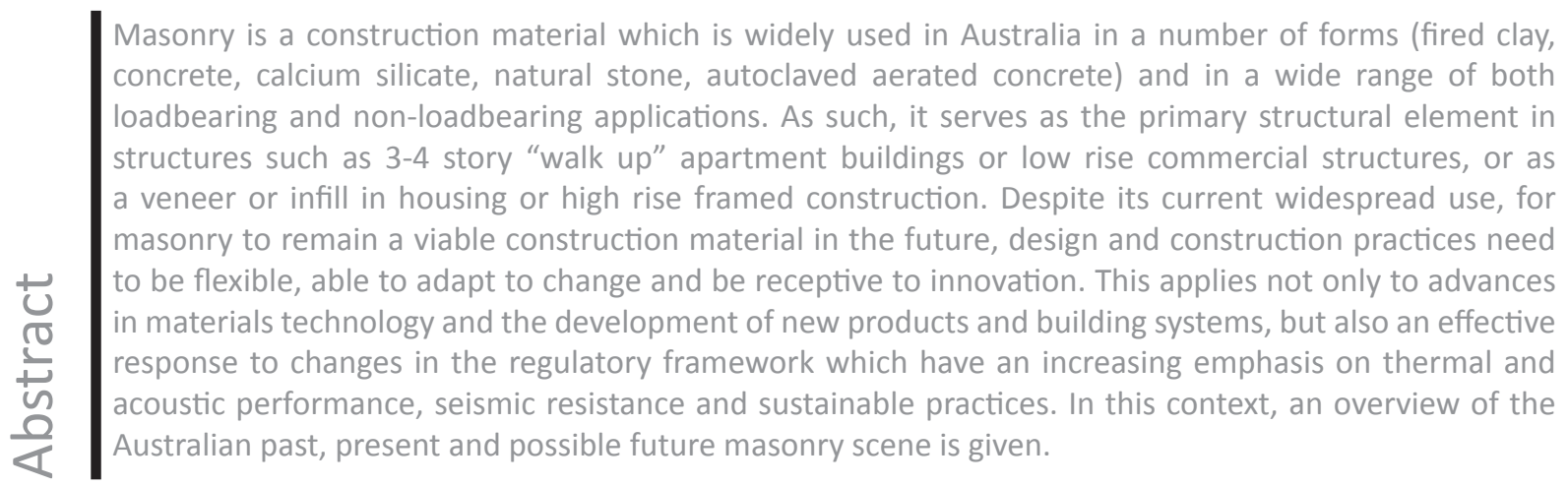

Keywords: masonry, Australia, past, current, future. 


\section{INTRODUCTION}

Masonry, along with timber, steel and concrete is one of the four primary construction materials used in buildings in Australia. It is used in a wide range of both loadbearing and non-loadbearing applications in a number of forms (predominantly fired clay and concrete, and to a lesser extent, autoclaved aerated concrete, natural stone and calcium silicate). As such, it may serve as the primary structural element in structures such as 3-4 story "walk up" apartment buildings or low rise commercial structures, or as a veneer or infill in housing or high rise framed construction. Masonry in its various forms is widely used because of its aesthetic qualities, its strength and its physical characteristics related to thermal efficiency, sound transmission and fire resistance. As Hogan states

[...] the appeal of masonry also lies in less tangible properties, such as its handcrafted persona, its link with history, and its old-world charm. As it has for centuries, masonry continues to symbolize craftsmanship, permanence, and quality [...] (HOGAN, 2003).

In many respects the Australian masonry industry is still very traditional and conservative, and to some extent complacent in responding to the development of alternative systems (a good example of this was the emergence of prefabricated and tilt-up concrete construction systems in the 1980's which made major inroads into the use of masonry in light commercial construction without any coordinated response by the masonry industry). However, there is certainly the potential to develop new and innovative products and systems and to build upon the state-of-the-art technology that is used in the manufacture of masonry bricks and blocks. It is rather incongruous that masonry units manufactured using these sophisticated technologies are then delivered to the site and still assembled unit by unit (often by semi-skilled labour) using techniques which have remained essentially unchanged for generations.

Despite its inherent advantages and traditional use, for masonry to remain a viable construction material in the future, design and construction practices need to be flexible, able to adapt to change and be receptive to innovation. This applies not only to advances in materials technology and the development of new products and building systems, but also an effective response to changes in the regulatory framework which have an increasing emphasis on thermal and acoustic performance, seismic resistance and sustainable practices. In this context, an overview of the past, present and possible future Australian masonry scene is presented.

\section{PAST DEVELOPMENT OF MASONRY IN AUSTRALIA}

\subsection{Masonry as a Material}

Masonry in various forms is one of the oldest building materials, dating back to at least $4000 \mathrm{BC}$. From ancient times to the present day, the basic nature of masonry has remained unchanged, with convenient sized masonry units being bonded together by some form of mortar to produce a composite walling material. Major technological advances such as effective kiln firing and the use of mortars containing lime and/or sand with pozzolanic properties resulted in larger and more durable structures. The industrial revolution also saw the development of Portland cement and the mechanisation of much of the brickmaking (and later block making) process.

Australia is an ancient continent with an indigenous culture dating back more than 40,000 years but with very little building construction due to their itinerant, "hunter-gatherer" lifestyle. The use of masonry in Australia dates back to the first European settlement in 1788 when a British penal settlement was established on the site of present day Sydney. One skilled brickmaker (James Bloodsworth) appeared on the convict list, and he was later to become a brickmaker and Superintendent of Works (GEMMELL, 1986). The first hand-made bricks were made in March, 1788 by convicts and this activity continued at an expanding rate both in Sydney and other subsequent penal settlements such as Newcastle and Port Macquarie. With the increasing availability of skilled labour, the volume and quality of bricks increased rapidly, with the first private brickyard being opened in 1802. Over the ensuing 100 years or so from the first European settlement, due to the progressive introduction of mechanization the quality and volume of bricks increased dramatically, with a large number of privately owned brickyards being established in both the city and country areas. These economies of scale produced a cheaper product which resulted in masonry (both brick and natural stone) being a preferred building material for a wide range of applications. 
In the twentieth century, the advent of Portland cement resulted in the emergence of additional masonry materials in the form of concrete bricks and blocks, calcium silicate bricks, and most recently, autoclaved aerated concrete units. This, combined with further advances in brick making technology, has resulted in a wide ranging set of economical masonry products being available to the consumer (typical Australian masonry units are shown in Figure 1). These changes have been accompanied by progressive rationalization of the industry, with a large number of small producers being replaced by a small number of large companies often producing the full range of clay and concrete products servicing a country which has one of the highest per capita uses of masonry in the world, approximately three times that of the USA (LAWRENCE, 2008).

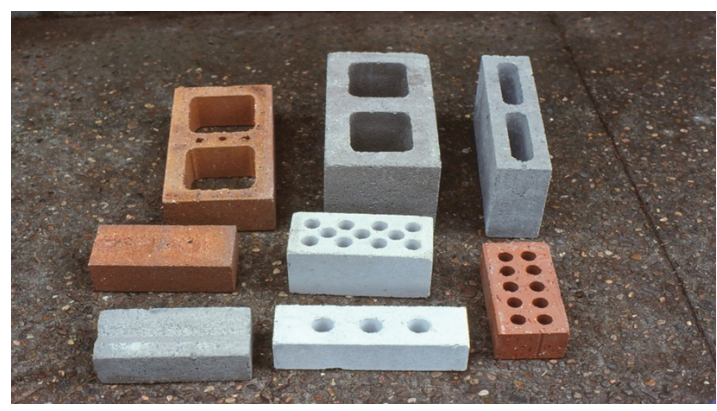

Figure 1. Typical Australian masonry units.

\subsection{Masonry Walling as a Structural Element}

Masonry is a material which is inherently strong in compression and weak in tension (as a result of the relatively low tensile strength of the material and particularly the low bond strength achieved between the masonry unit and the mortar). As a consequence, throughout history, masonry structures have been designed to avoid tensile stresses through the use of arches and domes to span openings. Masonry bearing walls were designed by specifying minimum thicknesses, which were governed not by the predicted level of compressive stress, but by the need to avoid tensile stresses being induced in the cross-section by the applied lateral loads. This traditional form of loadbearing masonry construction was common in Australia, with local government regulations specifying wall thicknesses simply as a function of their height. There are many surviving examples of this approach to the design of loadbearing buildings, particularly warehouses and bond stores built in the $19^{\text {th }}$ and early $20^{\text {th }}$ century (Figure 2). Clearly, these buildings were labour intensive and wasteful of both materials and floor space, but this method of design persisted in Australia until as recently as the nineteen sixties.

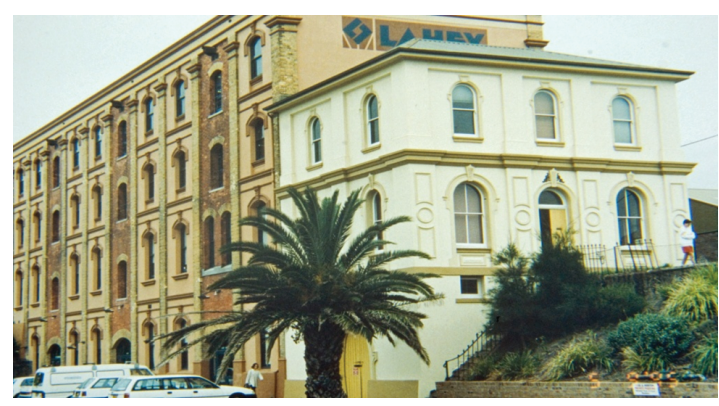

Figure 2. Traditional loadbearing construction.

So called "structural masonry" evolved in the 1950's and utilized cellular, bearing wall construction and shear wall action to transmit lateral loads. With this approach, the walls transmit lateral loads though in-plane rather than out-of-plane action with the floor slabs acting as horizontal diaphragms tying the walls together. More effective use is therefore made of the high compressive and shear strength of the masonry, as well as the small but finite tensile bond strength between the units and the mortar. Thin walls and an extremely efficient structural system results. Accompanying this change in design approach has been an increased understanding of the behaviour of masonry structures as a result of the significant world wide expansion in research activity that occurred over the latter half of the $20^{\text {th }}$ century.

In the Australia context, this approach to loadbearing design was pioneered in Perth in the 1960's with the construction of a series of high rise apartment blocks, demonstrating the viability of this form of construction (KRANTZ, 1968). On a smaller scale, the common 3-4 storey "walk-up" apartment buildings are based on similar principles (Figure $3 b$ ). The height limitations on unreinforced masonry loading structures imposed by the earthquake loading code now limits this form of construction to four stories.

\subsection{Codes and Regulations}

Prior to the 1960's, no Australian design codes for masonry existed, with British and North American standards being used. Separate codes for blockwork and brickwork were then produced, with the blockwork code being heavily influenced by North American practice, and the brickwork code by European (and particularly British) practices. As a result of this ad hoc development of design codes, there were major inconsistencies in the provisions and procedures for the design of clay 


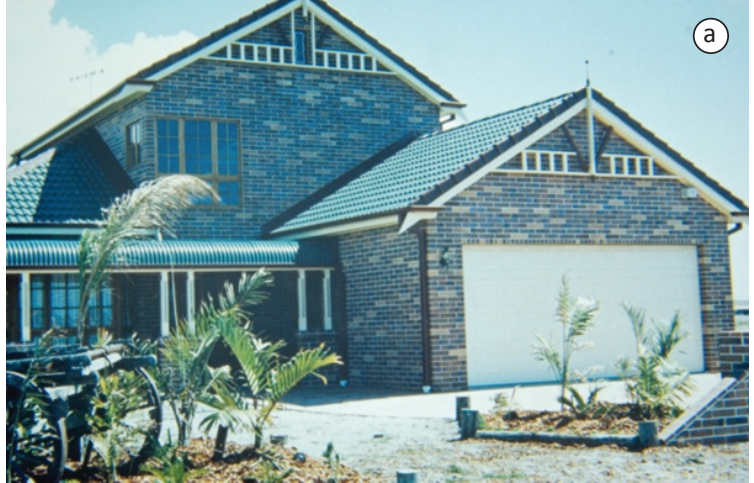

Typical domestic construction

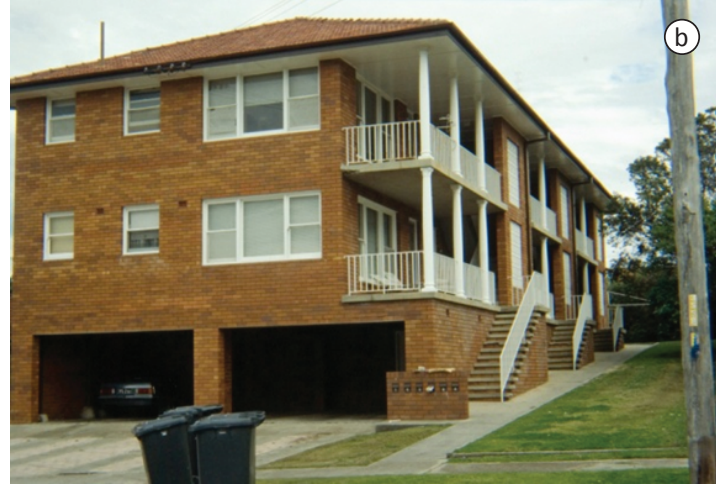

Low rise loadbearing apartment

Figure 3. Examples of current masonry usage a) Typical domestic construction; b) Low rise loadbearing apartment.

and concrete masonry. Many of these were arbitrary and historically based, with no technical justification (JOHNSTON, 1985).

In the 1980's it was realised that the brickwork and blockwork codes were outdated and in need of review, as major advances in the state of knowledge of material behaviour and design procedures had occurred as the result of research in Australia and overseas. During the period 1983-88 these standards were reviewed and rationalized, culminating in 1988 with the publication of the first unified Australia masonry code (AS3700). This also included the conversion from a working strength approach to one based on limit states and ultimate strength design. As part of this process in 1984, an innovative wall tie standard, introducing the concept of the experimental determination of in-situ strength and stiffness of ties was also introduced.

The advent of national building regulations defined in the Building Code of Australia (BCA) (AUSTRALIAN..., 1988) also changed significantly the approval regime in Australia, with a move away from highly prescriptive rules and regulations towards a performance based approach in both the BCA and associated standards. This permitted and encouraged a much more innovative approach to design. Since 1988, the associated codes to AS3700 (masonry units and segmental pavers, wall ties and accessories, mortar testing, damp-proof courses and flashings etc) have been progressively reviewed and updated and brought into line with AS3700, so that a unified set of codes now exists. The most recent version of AS3700 was published in 2011 (STANDARDS..., 2011).

The 1989 Newcastle earthquake resulted in an added emphasis on seismic performance in Australian Structural design codes. This unexpected event, although only moderate in magnitude, produced a disproportionate degree of damage (in excess of \$A1.5 billion), with much of this being to unreinforced masonry (MELCHERS; PAGE, 1992). The Newcastle earthquake also revealed widespread problems with the design, detailing, construction and maintenance of masonry structures, with buildings not complying with code requirements in many instances (PAGE, 1992). As a result of the increased emphasis on the seismic performance of buildings, a new earthquake loading standard was produced (STANDARDS..., 1994). This was subsequently referenced by the $\mathrm{BCA}$, thus mandating that earthquake loads be considered for all structures (including housing). As a consequence, subsequent versions of AS3700 have included specific seismic design requirements with some restrictions on the use of unreinforced masonry, particularly in relation to height limitations and effective tying to ensure system performance.

\section{CURRENT AUSTRALIAN MASONRY}

Masonry is widely used in Australia as a building material predominantly unreinforced and in the form of clay brick or concrete block, with brick masonry accounting for the greatest proportion of walling construction (see Table 1). There is also limited use of autoclaved aerated concrete masonry (AAC) as well as the occasional use of stone and calcium silicate masonry (all of these masonry types are covered by AS3700). The largest masonry market is in domestic construction, where brick veneer, and to some extent cavity brick, is the commonest form of walling, with single skin partially reinforced concrete masonry being used in tropical (cyclonic) areas. In recent years, various forms of 
Table 1. Typical Australian Usage of External Walling Materials (BIS Shrapnel).

\begin{tabular}{ccc}
\hline Walling material & 2010 Usage $\left(\mathrm{m}^{2} \times 10^{3}\right)$ & $\%$ Share \\
\hline Brick veneer & 13,424 & $37 \%$ \\
Full brick & 4,545 & $12 \%$ \\
Concrete masonry & 2,882 & $8 \%$ \\
Precast concrete \& tilt up construction & 8,156 & $22 \%$ \\
Colorbond (steel sheeting) & 2,831 & $8 \%$ \\
Fibre cement & 2,653 & $7 \%$ \\
Composite panels & 1,053 & $3 \%$ \\
Other & 1,157 & $3 \%$ \\
Total & 36,701 & $100 \%$ \\
\hline
\end{tabular}

lightweight construction have also become more popular as a masonry alternative. Brick masonry is also used in low rise loadbearing construction (such as 3-4 storey apartment blocks) and as infill and veneer in high rise framed construction. Fully or partially reinforced concrete masonry is used in commercial construction, particularly in high wind areas. Typical domestic and apartment applications are shown in Figure 3.

\subsection{Current Codes and Regulations}

All masonry materials and types are covered by the Masonry Structures Code AS3700-2011 (STANDARDS..., 2011). There is also a series of supporting standards related to ties and fitments, damp-proof courses etc. AS3700 is performance based with some deemed-to-satisfy solutions (LAWRENCE; PAGE, 2011). A recent significant addition has been the development of a new two-part standard specifically for masonry houses and other small buildings, designated AS4773 Part 1 (Design) and Part 2 (Construction) (STANDARDS..., 2010a, b). The provisions of this standard are consistent with the AS3700 provisions, but are in a user friendly, deemed-to-satisfy format allowing ease of use by not only engineers, but also architects, home designers and builders (LAWRENCE; PAGE, 2008).

The design actions for building design are contained in a suite of loading standards covering design actions, permanent and imposed actions, wind actions, snow and ice actions and earthquake actions (Standards Australia). These apply to all structures. Because of the increased emphasis on seismic design, AS3700 now contains specific detailing requirements for loadbearing and non-loadbearing masonry panels and height restrictions for unreinforced loadbearing masonry structures (these range from a maximum height of $15 \mathrm{~m}$ for structures founded on rock in areas of low seismic risk (ground accelerations less than or equal to 0.06 ), to $10 \mathrm{~m}$ for buildings on soft soils and higher seismic risk (ground accelerations greater than or equal to 0.11)). Any loadbearing masonry structure above this height must be reinforced and detailed to provide adequate ductility.

\subsection{Current Challenges}

With the continued introduction of new products and walling systems, and the increasing emphasis on building sustainability in all of its forms, there are a range of challenges confronting the masonry industry all of which have the potential to impact on its effective use.

\subsection{Workmanship and Site Supervision}

The construction of masonry buildings has a long and proud tradition, with the mason being a highly regarded craftsperson with a high level of skill and dedication. Unfortunately in recent years in Australia, with some exceptions, this tradition has not been upheld with the quality of workmanship and site control decreasing significantly. This trend was graphically illustrated in the aftermath of the 1989 Newcastle earthquake which produced a disproportionate amount of damage for the size of the tremor, with a large proportion of the damage being to unreinforced masonry. The poor general performance of masonry was the result of a combination of factors ranging from lack of involvement and poor design and detailing on the part of the structural engineer and architect, to lack of supervision and poor workmanship (PAGE, 1992).

\subsection{Labour Costs}

Traditional masonry construction is labour intensive and site based. High Australian labour costs, combined with poor site supervision and 
workmanship, has resulted in a worrying trend for the masonry industry with the development of alternate walling systems and materials which address or avoid these issues.

\subsection{Sustainability Issues}

In the context of climate change and global warming, there is an increasing emphasis on the need for sustainable building practices and in particular, efficient energy performance to minimize $\mathrm{CO}_{2}$ emissions. Traditionally building design in Australia has been governed by aesthetic and economic considerations with little attention being given to factors such as embodied and operational energy of building products and systems. This emphasis will increase with the implementation of a carbon tax (transitioning into an emissions trading scheme) to take effect across Australia from July, 2012.

Currently, the commonest form of house construction is brick veneer with cavity brick construction also being used to a limited extent. Lightweight construction (external boarding with a layer of insulation on a timber frame lined with plaster board) has also become more common. Often these systems incorporate air conditioning to provide internal thermal comfort with no attempt to optimise the thermal performance of the building using solar-passive design principles where the inherent thermal mass of masonry walling can be used to advantage.
With increasing emphasis on $\mathrm{CO}_{2}$ emissions, masonry is potentially disadvantaged because of the high levels of energy required in the manufacture of masonry units and cement. However, if the full life cycle of a building is considered, a different picture emerges. Recent life cycle assessment studies for a typical Australian home (THINK..., 2008) have shown that regardless of construction type, the operational energy for the house over its design life far outweighs the embodied energy of the materials, with emissions from embodied energy representing only $11 \%$ of the total emissions over a 50 year life cycle. Operational performance is therefore a key factor in the design of a sustainable housing system.

Over the last 10 years the Australian brick industry has been pro-active in research in this area including a major collaborative research project with the University of Newcastle involving full scale experimental studies and parallel analytical modelling of the thermal performance of Australian housing systems. A detailed report on the first phase of the project has been recently published (PAGE et al., 2011) and the results clearly show the advantages of an appropriate combination of thermal resistance and thermal mass in walling systems. Figure 4 shows some typical results from the observed performance of full scale housing test modules for an extreme summer's day in Newcastle. The indoor temperature profiles illustrate the ability of the cavity walling module to produce better levels of thermal comfort than the lightweight system. The significant lag between the peak external and internal temperature for the cavity wall system due to its thermal mass is also apparent.

\section{FUTURE IMPROVEMENTS}

The continued widespread use of masonry in Australia will be influenced by an effective response to range of factors:

\subsection{Sustainability Issues}

As discussed above, there will be an increasing emphasis on all aspects related to sustainability and particularly the reduction of green house gas emissions. This will require continued research and development into various aspects of masonry unit manufacture and subsequent use including:

- Innovations in unit manufacture including increased coring to reduce weight, volume of raw material and hence firing energy; improved firing efficiency by the inclusion of materials to the body with a calorific contribution as well as recycling in the form of the addition of used and waste materials; alternative fuels for kilns; and modifications to unit geometry and composition to increase wall thermal resistance;

- $\quad$ Development and use of low $\mathrm{CO}_{2}$ cements in mortars and concrete unit manufacture;

- Wider application and use of solarpassive design principles to maximize the ability of masonry walling systems to reduce operational energy of buildings; and

- $\quad$ Recycling and re-use of masonry units.

\subsection{Construction Techniques and Practices}

There are a range of design and construction techniques as well as site practices which have the potential to increase the efficiency of construction, reduce site labour problems and produce a better 


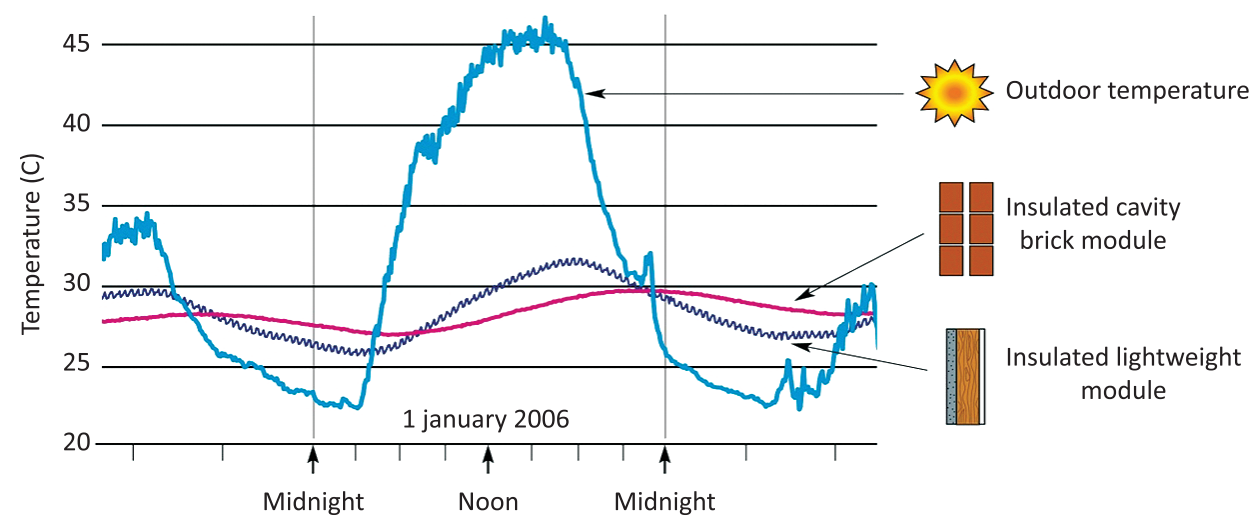

Figure 4. Thermal performance of cavity brick versus lightweight housing test modules.
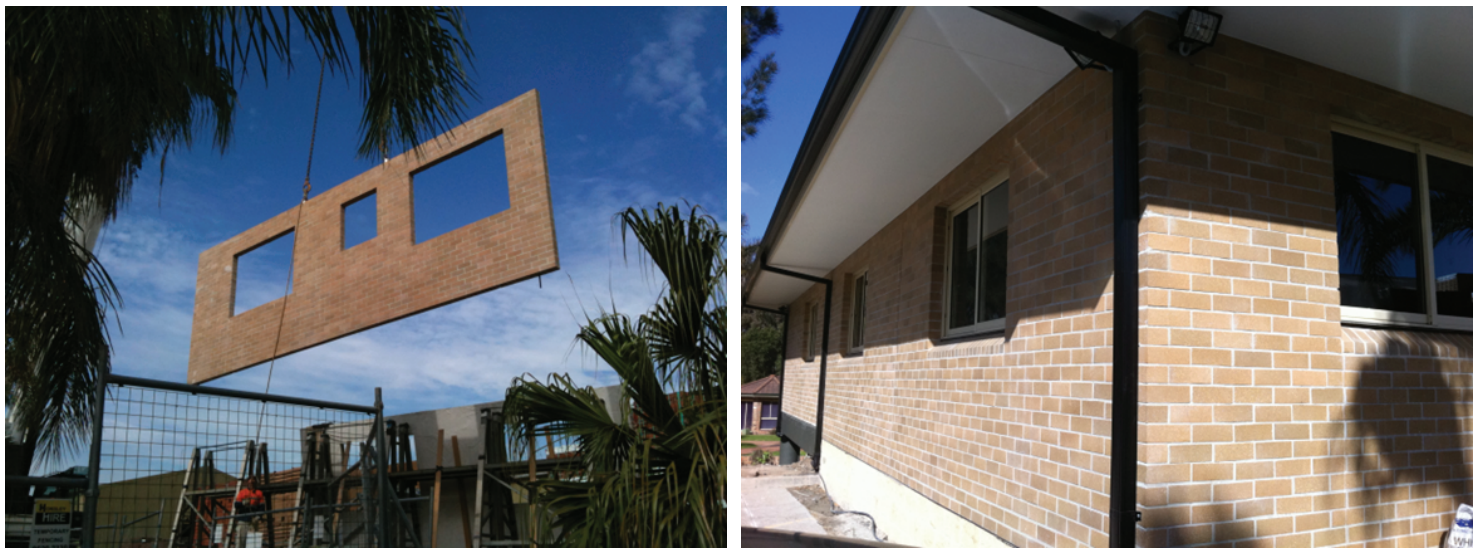

Figure 5. Prefabricated housing system.

quality product. This could include more effective education and training programs for designers, builders and tradesmen; the development of techniques and systems which overcome the inherent low tensile strength of masonry; innovations in laying techniques through the use of lightweight bricks and blocks of increased size to increase the speed of construction; the development of semi-automated laying systems; the use of thin bed mortars and/or dry stack modular systems etc.

\subsection{Prefabrication}

\section{SUMMARY AND CONCLUSIONS}

Masonry is widely used in Australia both as an architectural and structural material. This continues a strong tradition that has developed since European settlement in the $18^{\text {th }}$ century.

Despite increased competition with other walling systems and the increasing challenges associated with the move towards sustainability in building practice, masonry has the potential to remain a viable
Prefabrication is obviously an effective means of minimizing site construction problems, ensuring masonry quality and reducing construction times. Although prefabrication of masonry panels has been used successfully in Europe and elsewhere (HENDRY, 2001), previous attempts in Australia have met with only limited success. Given the increasing use of other forms of prefabrication for walling systems, it is likely that effective masonry systems will also emerge in the future. Figure 5 shows a recent example of a current Australian trial project for a prefabricated housing wall system.

and competitive provided the masonry industry is innovative, receptive to change and prepared to move away from traditional thinking and practices. In this context there is also likely to be an increased use of a system approach to buildings, with panelisation and off-site construction techniques to avoid workmanship and other site problems as well as the development of new and refined masonry materials. 


\section{REFERENCES}

AUSTRALIAN UNIFORM BUILDING REGULATIONS COORDINATING COUNCIL - AUBRCC. Building Code of Australia. Canberra: AUBRCC, 1988.

GEMMELL, W. And So We Craft from Six to Six - The Brickmakers of NSW. Angus \& Robertson, 1986.

HENDRY, A. W. Ways forward for masonry construction in the UK?. Masonry International, v. 15, n. 1, p. 1-4, 2001.

HOGAN, M. B. The masonry industry to-day and to-morrow. In: NORTH AMERICAN MASONRY CONFERENCE, 8., 2003, Clemson. Proceedings... Clemson, 2003. Keynote paper.

JOHNSTON, V. R. The new Australian Masonry Code. In: INTERNATIONAL BRICK \& BLOCK MASONRY CONFERENCE - IBMAC, 7., 1985, Melbourne. Proceedings... Melbourne, 1985. p. 1437-1448.

KRANTZ, D. Calculated Brick Bearing Wall Construction - What? Why? How?. Perth: Advanced Press, 1968.

LAWRENCE, S. J. Masonry codes and regulations - past, present and future. In: AUSTRALASIAN MASONRY CONFERENCE, 5., 1998, Gladstone. Proceedings... Gladstone, 1998. p. 219-225.

LAWRENCE, S. J.; PAGE, A. W. New Australian standards for masonry in small structures. In: INTERNATIONAL BRICK \& BLOCK MASONRY CONFERENCE - IBMAC, 14., 2008, Sydney. Proceedings...University of Newcastle, 2008.

LAWRENCE, S. J.; PAGE, A. W. Masonry Structures Standard AS3700-2011: an overview. In: AUSTRALASIAN MASONRY CONFERENCE, 9., 2011, Queenstown. Proceedings... Queenstown, 2011. p. 435-442.

MELCHERS, R. E.; PAGE, A. W. The Newcastle Earthquake. Proceedings of The Institution of Civil Engineersstructures and Buildings, v. 94, p. 143-156, May 1992. http://dx.doi.org/10.1680/istbu.1992.18783

PAGE, A. W. The design, detailing and construction of masonry - the lessons from the Newcastle Earthquake. Australian Civil Engineering Transactions, Engineers Australia, Camberra, v. CE 34, n. 4, p. 363-353, 1992.

PAGE, A. W. et al. A study of the thermal performance of Australian walling systems in housing. Priority Research Centre for Energy, The University of Newcastle, 2011. Disponível em:<http://www.thinkbrick.com. $\mathrm{au} /$ thermal-performance-and-climate-design>.

STANDARDS AUSTRALIA. AS1170.4: Structural Design Actions Part 4 - Earthquake Actions in Australia. Sydney: Standards Australia, 1994.

STANDARDS AUSTRALIA. AS4773.1-2010: Masonry in Small Buildings. Part1: Design. Sydney: Standards Australia, 2010a.

STANDARDS AUSTRALIA. AS4773.2-2010: Masonry in Small Buildings. Part 2: Construction. Sydney: Standards Australia, 2010b.

STANDARDS AUSTRALIA. AS3700-2011: Masonry Structures. Sydney: Standards Australia, 2011.

THINK BRICK AUSTRALIA. 2008. Disponível em: <http://www.thinkbrick.com.au/sustainability>.

\section{ACKNOWLEDGEMENTS}

Think Brick Australia has supported masonry research and a Chair in structural clay brickwork at the University for the past 20 years. Their support is gratefully acknowledged.

DADOS DOS AUTORES

(i) Emeritus Professor, School of Engineering, The University of Newcastle, Australia, adrian.page@newcastle.edu. 